\title{
Human health in systemic adaptation to climate change: insights from flood risk management in a river basin
}

\author{
Timo Assmuth ${ }^{1,2} \odot \cdot$ Tanja Dubrovin $^{3} \cdot$ Jari Lyytimäki $^{1}$
}

Published online: 21 November 2019

(c) The Author(s) 2019

\begin{abstract}
Human health risks in dealing with floods in a river basin in South-Western Finland are analysed as an example of scientific and practical challenges in systemic adaptation to climate change and in integrated governance of water resources. The analysis is based on case reports and plans, on literature studies and on conceptual models of risks and risk management. Flood risks in the Northern European study area are aggravated by melt- and storm-water runoff, ice jams and coastal flooding. Flood risk assessment is linked with management plans based on EU directives as applied in the case area. National risk management policies and procedures of increasing scope and depth have been devised for climate change, water resources and overall safety, but an integrated approach to health risks is still largely missing. The same is true of surveys of perceived flood risks, and participatory deliberation and collaborative planning procedures for flood risk management in the case area, specifically for adaptive lake regulation. Health impacts, risks and benefits, socio-economic and systemic risks, and overarching prevention, adaptation and compensation measures are not fully included. We propose a systematic framework for these extensions. Particular attention needs to be given to health risks due to flooding, e.g. from water contamination, moist buildings, mental stress and infrastructure damage and also from management actions. Uncertainties and ambiguities about risks present continuing challenges. It is concluded that health aspects of flooding are complex and need to be better included in assessment and control, to develop more integrated and adaptive systemic risk governance.
\end{abstract}

Keywords Flood $\cdot$ Climate $\cdot$ Health $\cdot$ Systemic risks $\cdot$ Integrated assessment $\cdot$ Collaborative governance

\section{Introduction}

Flood risks constitute a key challenge notably in adapting to climate change and variability (CRED 2015). In Finland, severe floods are not as common as in some other countries (EEA 2010; cf. Tanoue et al. 2016), but estimated aggregate losses due to coastal flooding of major Finnish cities are on a medium level in the EU (Prahl et al. 2018). Also in Finland, the economic losses vary widely, for instance, from ca. $3 \mathrm{M} €$ in the 1990s to $8 \mathrm{M} €$ in 2004 and to $17 \mathrm{M} €$ in 2005, of the latter estimate $12 \mathrm{M} €$ from the severe coastal flooding

Timo Assmuth

timo.assmuth@hotmail.com

1 Environmental Policy Centre, Finnish Environment Institute (SYKE), Helsinki, Finland

2 Helsinki, Finland

3 Freshwater Centre, Finnish Environment Institute (SYKE), Helsinki, Finland that year (Sane and Huokuna 2008). These loss estimates are dwarfed by those assigned in high-risk localities to rare floods. Moreover, some types of impacts and risks have been considered insufficiently, and many risks are projected to increase and change (Parjanne et al. 2018). Impact and risk estimates are thus uncertain, but at times highlighted in professional, media and social media debates.

Floods, their impacts and their controls influence, and are being influenced by, a host of natural and societal processes (Peltonen-Sainio et al. 2017; Tuomenvirta et al. 2018). The challenges to human health from floods are increased by climate change and by other systemic transitions (McMichael and Hales 2006). While floods occur naturally, anthropogenic factors can boost their frequency, magnitude and impacts. Floods bring benefits besides risks, also to human health due to the renewal of nutrient storages and biotopes. Nevertheless, the human health effects of floods can be devastating, and can impact systems far beyond the flooded area, with repercussions on private and public economies (Schmitt 
et al. 2016; Unterberger 2018), on overall welfare and on other societal systems (Hildén et al. 2016).

In Finnish regulation and official guidance, health impacts of flooding have not been extensively accounted for, although health is a prime objective of national flood risk management legislation (Finnish Parliament 2010). This contrasts with the accounts of impacts from floods on property (MoE 2017), on infrastructure and safety (MoI 2019), on agriculture and increasingly also other livelihoods (MoAF 2011) and on economy as a whole (Perrels et al. 2010; Pilli-Sihvola et al. 2016). Even though such accounts in other sectors sometimes refer in passing to health, it has been considered insufficiently in connection with floods. Also the Climate Act (Finnish Parliament 2015) referes only in passing to health in the context of floods. Here, the goal of "Health in all Policies" (Leppo et al. 2013) is not reached, as is the case also in many other regions (WHO 2016), implying an important gap in knowledge and practice.

Finnish research on climate-health links has focused on adverse health impacts of high temperatures (Näyhä 2005), also of water (Karvonen et al. 2010), allergens (Haahtela et al. 2013), vector-borne diseases (Laaksonen et al. 2010; Juntunen et al. 2017) and food production (Molarius et al. 2010). Only some studies have addressed related strategies, such as Helama et al. (2013), regarding suicide prevention and climate warming, and Sairinen et al. (2010), regarding health impacts of climate change in rural adaptation. On the other hand, flood risks and their management have been studied increasingly in the context of climate change (Silander et al. 2006; Söderholm et al. 2018). Yet, the specific links between flooding and human health in Finland have been considered seldom and narrowly, mainly implicitly in risk mapping and planning or in connection with damage from floods to buildings and infrastructure (Alho et al. 2008; Lonka and Nikula 2008; Mäntylä and Saarelainen 2008; Wahlgren et al. 2008).

There is a lack of information in this area also globally (WHO 2016). While specific health effects from floods have been often studied (Saulnier et al. 2017), only some work has been done on systemic risks to health and wellbeing (Lane et al. 2013), on strategic decisions and benefits (Landeg et al. 2019; Olanrewaju et al. 2019), on economics of health impacts (Schmitt et al. 2016) or on the capacity of those exposed (Ryan et al. 2019). Bouzid et al. (2013) noted the absence of systematic reviews of the effectiveness of interventions to reduce health impacts from climate change especially regarding floods. Some models of benefits from flood control have also omitted health (Pagano et al. 2019). The study by Houghton and Castillo-Salgado (2017) on health benefits of green building design and community resilience to flooding constitutes one of the few cases where these aspects have been systematically evaluated.
We thus set out to explicate concepts, identify key issues and outline methodological approaches in the analysis and governance of risks to human health associated with flooding, especially in the context of systemic adaptation to climate change. In applying and modifying generic approaches in a specific case, our objective is also to compare the risk governance conditions and developments in one country and region with those reported in others.

\section{Case and methods}

\subsection{Study area}

The Kokemäenjoki river basin represents a system where procedures have been actively developed and are in place for flood control and for the overall governance of water resources with respect to hydrological, technical and broader environmental and socio-economic impacts (Verta and Triipponen 2011; Dubrovin et al. 2017b), but where adaptation to climate change and related health risk issues have surfaced more recently (Assmuth et al. 2016; Söderholm et al. 2018). The river basin of Kokemäenjoki is the fourth largest in Finland, with a catchment of $27000 \mathrm{~km}^{2}$ and mean flow in the delta of $245 \mathrm{~m} \mathrm{~s}^{-1}$. As typical in Finland, the basin in the upper reaches includes many lakes (comprising an area of $11 \%$ of the basin), two of them flanking the large city of Tampere. The river discharges to the Baltic Sea through the City of Pori and a coastal wetland delta (Fig. 1).

Flooding takes frequently place in the River Kokemäenjoki. In a Northern location, flooding is regular during spring snowmelt, in addition to autumn and winter rains. The river and its lakes as well as the coastal delta also regularly freeze over, influencing flows and winter floods (Koskinen 2006). Two significant flood risk areas along the river, Pori and Huittinen, have been subject to increasing flood risk assessment and risk management planning according to the EU Floods Directive (EP and EC 2007) and the national legislation (Rajala 2013). Climate change is expected to increase floods risk in the river due to increasing autumn and winter floods, while spring snowmelt floods are likely to decrease due to warmer winters with less snow (Veijalainen et al. 2010, 2017; Söderholm et al. 2018). Also coastal floods are projected to increase with rising average sea levels and more frequent storms (Pellikka et al. 2018).

The river is profoundly altered and many of its lakes are regulated (Fig. 1), mainly for waterpower generation and flood prevention (Verta and Triipponen 2011). The river and its lakes are used also for crop irrigation and animal husbandry, fishing (mainly recreational) and other recreational purposes, permanent and free-time housing on shores, water traffic, nature conservation and as recipient of treated wastewater. Due to these multiple uses, the watercourse has 


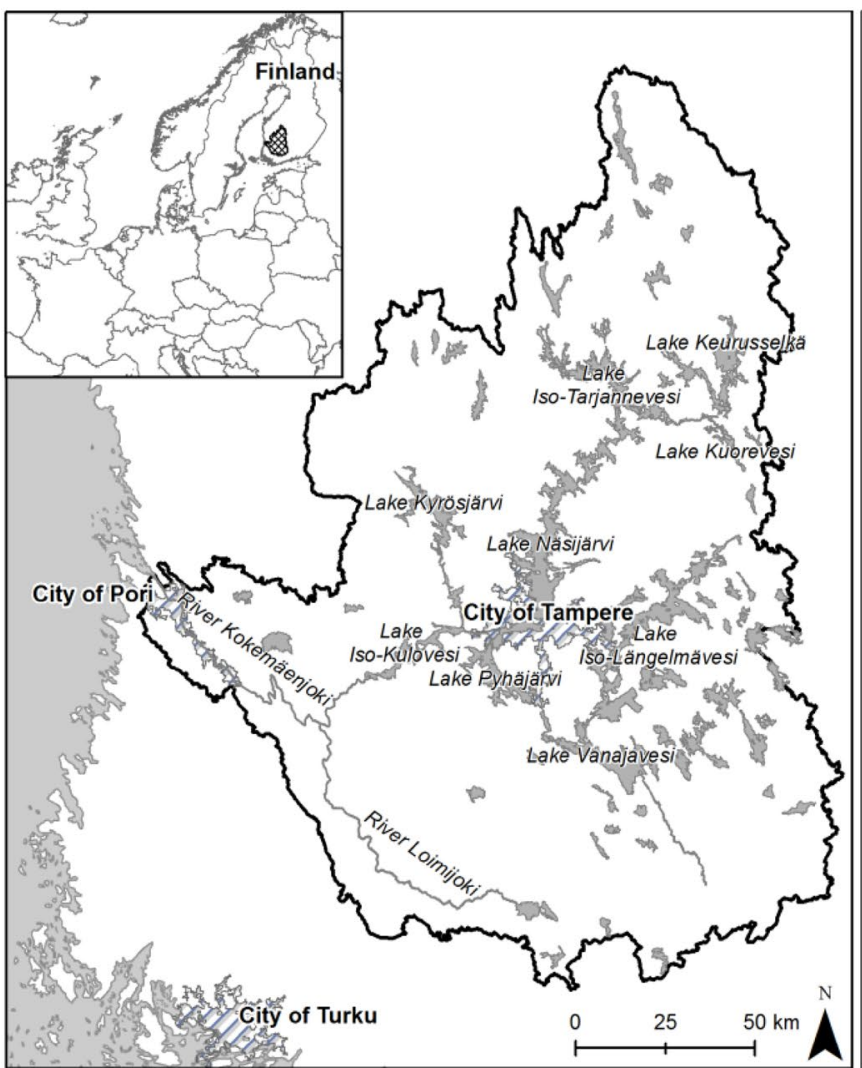

Fig. 1 Map and hydrological system diagram of the Kokemäenjoki river basin with the main lakes and river stretches. The principal inland city of Tampere, the discharge to the sea through the City of Pori and the pipeline transfer of water through aquifer recharge to

been subject to statutory multi-actor water resource planning and governance for decades (NBW 1984; Marttunen et al. 2004; Marttunen 2011). The natural flow of the river has been extended by diversion of part of its water to a managed groundwater recharge area from which the region of Turku obtains its potable water (Lyytimäki and Assmuth 2015).

\subsection{Methodological approaches}

We apply previous generic frameworks for integrated assessment and governance of systemic risks to health, environment and safety (IRGC 2005; Morris et al. 2006; Assmuth and Hildén 2008; Briggs 2008; Finkel 2011; Quigley and Luke 2019) and to watershed governance (Parkes et al. 2010; Verta and Triipponen 2011; VARELY 2015). We thereby focus on strategic management in connection with floods. We define risks as functions of the probability and consequence of unwanted events, of hazard and vulnerability and of probability, exposure and vulnerability or susceptibility (cf. Kiljn et al. 2015). We frame risks broadly, to include benefits from risk prevention, reduction and compensation (cf. Penning-Rowsell et al. 2010; Assmuth et al. 2016). In

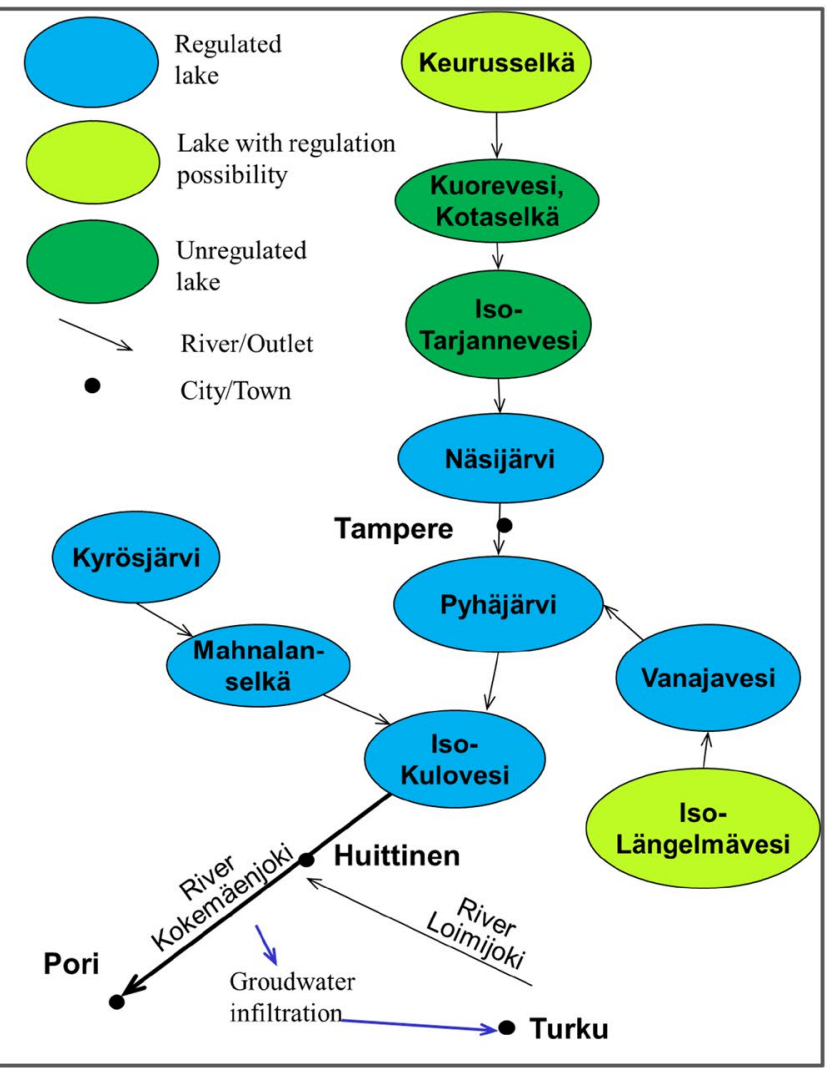

potable water in the region Turku, outside the actual river basin, are shown (by Hjerppe, based on SYKE hydrological map service; righthand side modified from Söderholm et al. (2018))

applying these frameworks to links between floods and health in our case, we use case-relevant information on multiple scales. The information sources include published reports and plans, documents describing local conditions, historical accounts and flood information systems mainly of the Finnish Environment Institute.

In contextualizing the case, we utilize comparative evaluations of scientific literature based mainly on PubMed and Web Of Science searches. These sources involve various perspectives of flood risks and impacts and of health. The perspective has often been biomedical or technical and preoccupied with disease as a direct consequence of flooding. We define health more broadly as an entity including physical, mental and social well-being (WHO 2006), and as a dynamic salutogenic process instead of a risk-dependent state (Antonovsky 1996). Based on qualitative structured analysis of the case and of pertinent literature, we then build a conceptual systems model of integrated flood health risk governance. Quantitative analysis is beyond our scope, due to the lack of information on flood-health links and to our focus on adaptive governance. However, we include relevant quantitative estimates of flood occurrence, vulnerability and 
damages, assess uncertainties and discuss their implications for methods and practices.

Our approach is predicated on complementary notions of knowledge and hence various ways of framing risks, impacts and decisions (Assmuth et al. 2010, 2016). In keeping with this, in adaptive governance we include participatory processes of deliberation, collaboration and learning (Faulkner et al. 2007; Benson et al. 2015) besides technical management. We complement previous analyses by addressing specifically health issues and their links with other areas and by broader and more systematic consideration of risks, impacts and options.

\section{Results}

\subsection{Flood risk management in Finland and its relation to other areas of governance}

According to the EU's Floods Directive (EP and EC 2007), implemented in Finnish legislation in 2010 (Finnish Parliament 2010; Finnish Government 2010) in the context of the Water Framework Directive, flood risk management takes place on the basis of flood hazard and risk mapping and by flood risk management plans and associated procedures. These were established already during the past decades (WGFR 2009; Rajala 2013) and have been rapidly developed (Verta and Triipponen 2011; Parjanne et al. 2012). They have been superimposed on traditional flood control planning and on extant legislation and institutions, such as presently particularly the Regional Centres for Economic Development, Transport and the Environment, assisted by Finnish Environment Institute (SYKE 2019a, b, c, d, e, f). Consequently, 22 important flood risk areas have been defined nationally in Finland, 4 of them recently, while 3 areas have been removed from this category. These areas contain 40,000 inhabitants, 25,000 buildings of which 50 deemed to be hard-evacuated, $1800 \mathrm{~km}$ of transport routes and 200 facilities or sites dangerous to the environment (SYKE 2019b).

Additionally, the Rescue Act (Finnish Parliament 2011) influences flood risk management within disaster response, assigning duties to regional rescue authorities. Municipalities in many sectors, from rescue to technical and environmental services, are in a key position in local activities. The links to climate and energy policies have been continuously reinforced (MoE 2017; MoLE 2017). Thus, national policies, strategies and plans of several sectors back up and interact with management activities at river basin and local levels.

Flood risk management is consequently organized in operative bodies that involve regional and local authorities mainly for water, environment, safety and enterprise (on the regional level, the present regional centres for economic development, transport and the environment). Finnish Environment Institute (SYKE) acts as a central expert body. Operative bodies also include prominent water power generators. Other actors such as other users of the watercourse have an increasing role (MoE 2015).

Many of these areas of risk management have been subject to detailed analysis and development, such as risk mapping (Alho et al. 2008) and guidance for building (Parjanne and Huokuna 2014). Regulation, planning and development of rescue services constitute another key area of development (Raivio 2006; Finnish Parliament 2011; MoI 2016). Also more comprehensive approaches encompassing additional sectors and actors have been included in flood risk management policies, programmes, plans and related advice, even in the case area. Several technological and institutional measures are inherently included and integrated in land use planning and have been implemented with regard to flood control on some level (cf. Peltonen et al. 2006; MoE 2015).

Lake regulation is a key means for managing water levels, volumes and flows in the case river basin (Dubrovin et al. 2017b; Söderholm et al. 2018). Its various uses are to be reconciled, but those for waterpower generation have traditionally dominated in Finland, while uses for fishing, recreation or the protection of aquatic environments have generally had lower priority. Flood control in inland watercourses has been also traditionally linked to the needs of agriculture, in addition to the protection of buildings and industries, roads and waterways, and other infrastructure.

The coastal City of Pori is one of the 22 nationally important flood risk areas. Exceptional floods have been experienced here, such as the spring floods of 1677, 1936, 1951 and especially 1899, and the winter floods of 1755-1956, 1944 and, especially in Pori, of 1974-1975 and 2004-2005 (Rajala 2013). Consequently, flood protection measures of variable and increasing extent and efficiency have been implemented here and in other high-risk areas over the centuries. They include dredging, diking, channelling, and dams, walls and embankments which are linked also to dam safety based on the Dam Safety Act (Finnish Parliament 1984). Moreover, control measures include spatial planning and statutory EIA (Finnish Parliament 1994; Finnish Government 1994). These measures play a key role in developing adaptive risk management (City of Pori 2009; Fig. 2). However, links with health and general welfare are yet seldom dealt with explicitly and in depth, or brought to bear on the practical implementation of assessments and plans.

\subsection{Identification and assessment of flood risks in previous procedures and contexts}

The flood risks in the Kokemäenjoki river basin have been framed in the statutory flood risk management plan (Verta 


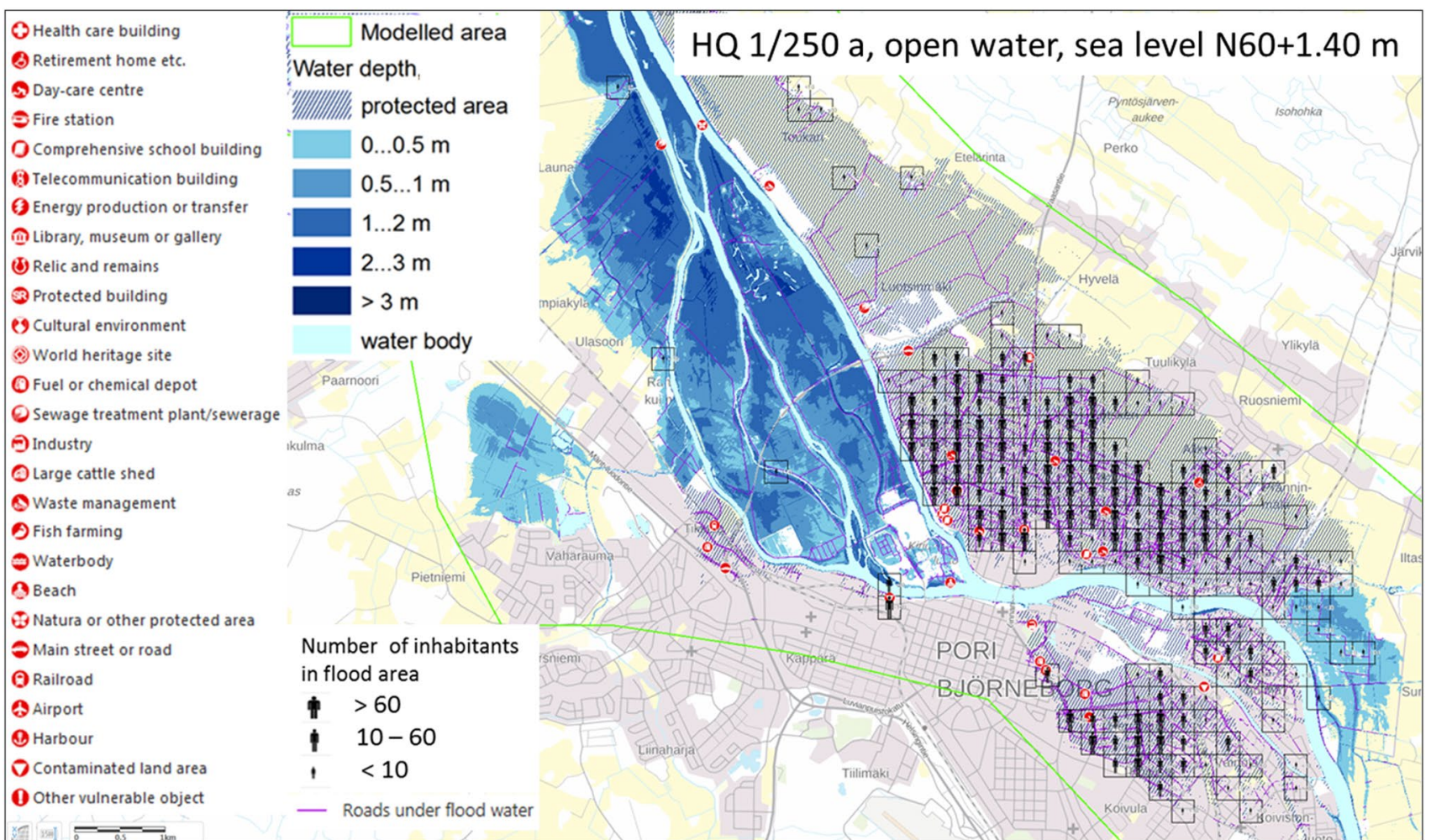

Fig. 2 Flood risk map of the City of Pori. The map utilizes GIS based data on, e.g. housing, potentially polluting facilities, high-vulnerability buildings and water intake structures, in addition to flood hazard maps (shown for a flood with discharge of 250-year recurrence time and sea level of $1.4 \mathrm{~m}$ above mean), based on the national Finnish flood map service (SYKE 2019c), elaborated by Mikko Sane and Triipponen 2011; VARELY 2015) which emphasize geographical representations, and frequencies of risks and their direct monetary valuation. Flood risk management plans in principle cover the cycle of risks and their management from risk and flood prevention to protection and preparedness (Huokuna 2012). However, framing of risks in some other respects is often restricted, such as regarding societal drivers and root causes, adjacent sectors such as health care, social impacts, risks of management actions (counter-veiling risks) and risk compensation, all of which are important in governance. Among drivers for management, climate change has gained increasing attention (Söderholm et al. 2018).

Geographically, the regional flood risk management plan (VARELY 2015) encompasses the whole river basin, whereas local flood control involves specific plans and procedures, e.g. for storm-water floods. Risks to potable water in the region of Turku through artificial groundwater recharge have not yet been included in operative flood risk management. The highest flood risks in the basin are located along the river itself, especially around the City of Pori (Fig. 2) and the small rural town of Huittinen (Fig. 3). Lehtoranta et al. (2016) found awareness of flood risks among inhabitants of Huittinen especially regarding impacts on transport, fields, gardens, lives, buildings and wastewater treatment systems.

In terms of time, risks have been considered mainly on the scale of decades and with recurrence times of up to 1000 years. Seasonally, winter-time floods are important along with floods due to excessive runoff from spring snowmelt and autumn rains, because in winter flooding through frazil and ice jams is frequent in the river. Climate change has been projected to increase winter rains and render spring floods earlier and may impact frazil (Aaltonen et al. 2010).

The focus in statutory operations is on direct and immediate risks. Flood control has been further focused on water quantity instead of quality although these are linked, specifically as flooding may impair water quality. Physical impacts and risks from flooding have been routinely mapped, while perceived risks (Lehtoranta et al. 2016) and collaborative capacities (Söderholm et al. 2018) have been more seldom investigated.

Flood damage assessments for the river basin have focused on monetary losses (especially insurable) and have excluded many other losses, usually also indirect damage (Silander and Parjanne 2012; cf. FFFS 2014). The damage 


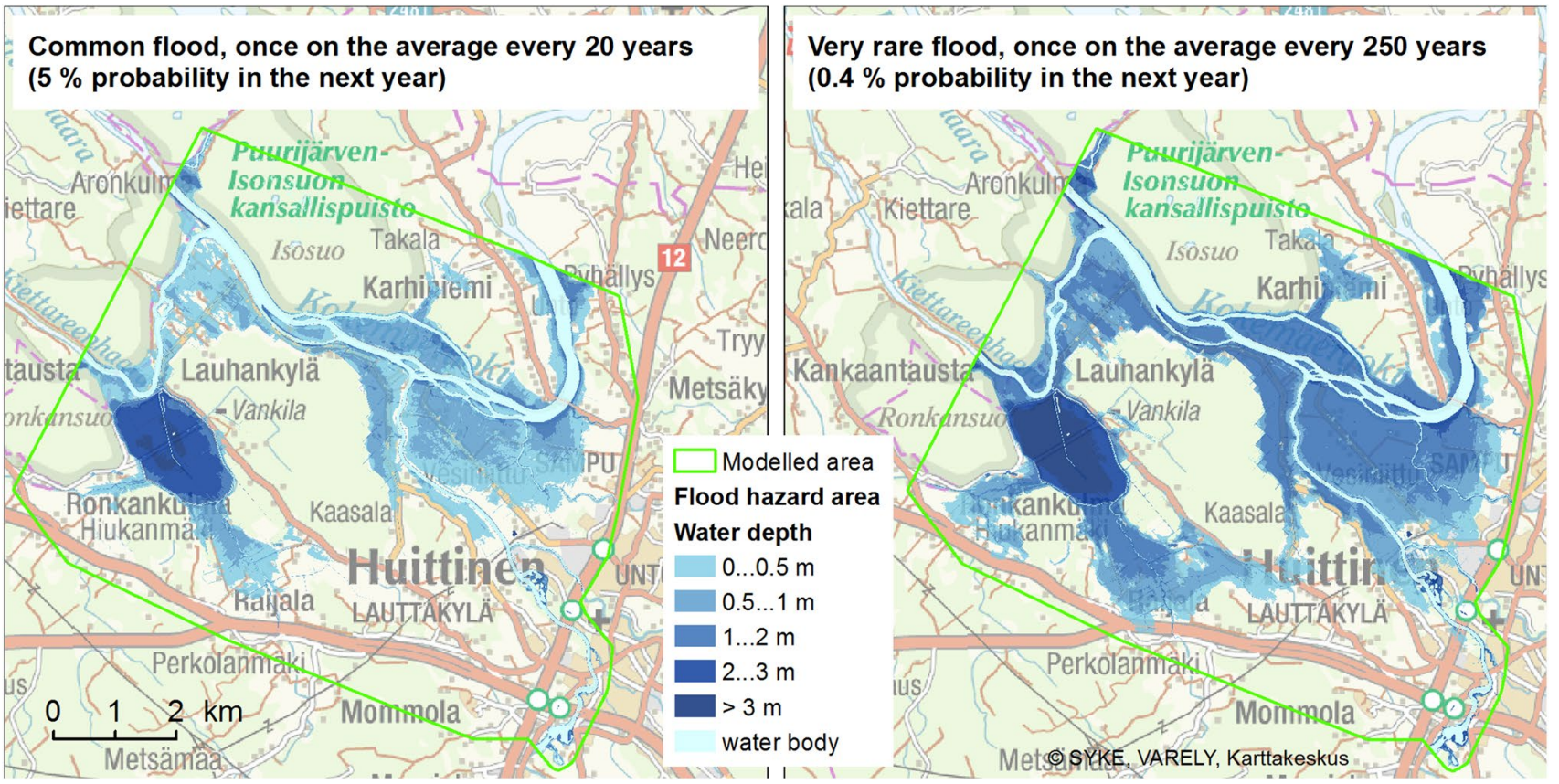

Fig. 3 Estimated frequencies and extents of flooding in the Huittinen area in the lower reaches of the River Kokemäenjoki (cf. Fig. 1). The maps have been processed by Mikko Sane on the basis of the national Finnish flood map service; cf. Lehtoranta et al. (2016); SYKE (2019c)

estimates are dominated by worst case scenarios for City of Pori (Dubrovin et al. 2017a). Floods in Pori can be caused by several factors and their combinations: high discharges, frazil or ice jam, and high sea levels. In a rare flood, if the flood protection levees are overtopped, the estimated direct damage in Pori increases to hundreds of $\mathrm{M} €$, and inhabitants in the flooded area to ca. 10,000 (VARELY 2015; Koskinen 2006). Damage estimates are uncertain as both the extent of the flood and the impacts, many of them indirect (Koks et al. 2015), depend on framings and are unforeseeable. Including indirect losses, the total damage of a worst case flood in Pori has been estimated to increase to several G€ (City of Pori 2010). This tallies with macroeconomic scale losses of severe floods estimated in the US and EU to reach $0.3-11 \%$ of GNP (Unterberger 2018), which for Finland would amount to $0.6-3 \mathrm{G} €$ annually. Great uncertainties, however, apply also to these estimates and also to impacts and risks to human health and well-being.

\subsection{Development of adaptive flood control approaches as an alternative to statutory lake regulation}

In order to develop improved approaches to flood control and health, management strategies need to be evaluated. We use as a starting point the analysis of Söderholm et al. (2018) of lake regulation and associated damages, benefits and risks in the Kokemäenjoki river basin. The analysis examined the characteristics and consequences of options, specifically watercourse regulation schemes focused on lake levels, and alternatives. Several other analyses, plans and recommendations have also been made for the case river basin (Marttunen et al. 2004; Dubrovin et al. 2017a,b).

Estimable flood damages, mainly direct costs as proposed by Silander and Parjanne (2012) using international literature, were compared between present management and a damage-minimizing optimizing strategy, in a severe winter flood scenario. The options were formulated and evaluated with a broad group of stakeholders engaged in flood control and related activities.

It was found in the analysis by Söderholm et al. (2018) that by altering the statutory watercourse management system and its objectives and control means to better consider flood risks, the damages especially in the City of Pori could be significantly reduced, resulting in reduced total losses. In addition, a strategy not focused only on flood damage minimization during flood but including also proactive regulation could further reduce losses. The realization of options and their consequences, however, involves considerable uncertainties and would depend (in the winter flood scenario), e.g. on whether, how and to what degree controlled ice cover steering of flows is possible and whether dams would hold increased water levels for emergency storage.

Also, the distribution of risks and benefits from management strategies between regions (upstream lakes and downstream river-plains including the City of Pori) could be identified as a problematic issue that involves uncertainty and 
ambiguity of value judgments and political choices associated with conflicting interests of sectors and actors. In a historical account of such conflicts and their resolution in flood risk management in the case river basin, Rajala $(2013,66)$ emphasized the shift of focus from agricultural goals over water transport and subsequently waterpower generation to environmental protection and the importance of associated competing interests.

\subsection{Identification and assessment of health risks of floods}

The protection of human health is among the foremost objectives of the national legislation (Finnish Parliament 2010) based on the Floods Directive. However, health impacts and risks of floods also in the present case have not been explicitly addressed in detail although some of them are implicit in risk management planning (e.g. VARELY 2015). The aspects or factors of health risks that are included in statutory flood risk management plans mainly include the amount of inhabitants in the flood risk area, and the location of health care facilities, hard-evacuated facilities and wastewater treatment plants and other waste management facilities (Table 1).

For more extensive assessment, health impacts and risks may be classified based on various criteria that overlap, including direct impacts, indirect impacts, e.g. through infrastructure and economy-wide effects, and impacts and risks of flood control and adaptation (Table 1). Health impacts and risks of flooding are diverse and include in worst cases drowning and other lethal accidents, in more numerous cases of injuries or diseases, and in still other mental health impairment also due to evacuation (Lamond et al. 2015). Impacts and risks are moreover caused in multiple stages. This multiplicity of health impacts, risks and vulnerabilities is reflected in risk management and risk governance (Fig. 4).

An important type of health impacts caused directly by water intrusion in buildings and other spaces is due to moisture. This has been reported in studies from other countries (Azuma et al. 2014). Some of these impacts are immediate, as with acute respiratory infections, but a more important impact may in many cases be health impairment due to exposure to moulds promoted by moisture in living space especially through allergic reactions. Such health problems have been found in many Finnish schools (Borràs-Santos et al. 2013) but have not been studied specifically in relation to floods. Besides residents, disaster response workers may be severely exposed (Johanning et al. 2014).

Water pollution is a key health risk especially with malfunctions in wastewater purification plants or other waste treatment facilities caused by flooding (e.g. due to electricity failure), but also through leaching from household, farm animal and industrial wastes. Besides organic wastes and harmful organisms, dangerous chemicals can leak from facilities at risk (cf. 3.1). These contaminants may extend far with flood waters and even through water transfer systems and may incur great cleanup costs especially in flooded buildings but also more extensively (Assmuth et al. 2016). Damage to ICT infrastructure can significantly increase and modify such risks (Dawson et al. 2018).

Health impacts and risks from evacuation are potentially important, as a large population may be exposed, and may exceed adverse immediate impacts. For instance, in the $\mathrm{EU}$, half a million people were displaced due to floods in 1998-2009, while the number of direct fatalities was 'only' 1126 (EEA 2010). Also in Finland, during a rare countrywide flood, many of the 40,000 exposed inhabitants in the 22 high-risk areas (SYKE 2019b) might suffer losses or have to be evacuated. Mental health impacts of floods and flood risks are potentially important in a variety of ways, also for social cohesion (Greene et al. 2015). They may be downplayed as they are not as concrete and tangible as physical impacts.

Counter-veiling health risks of flood control pose potentially important limitations to the efficacy, feasibility and acceptability of risk management, and require analyses of indirect, also unintended adverse consequences. For instance, health problems from relief responses to those to be relieved and to relief personnel are to be avoided (Johanning et al. 2014), by Hippocrate's rule ("first of all, do not do harm"). More generally, tradeoffs between strategies and options with widely varying requirements and consequences are needed in every step of risk management. We identified such tradeoffs between subregions in the river basin and between activities of different administrative sectors.

Health impact assessment (HIA) and health risk assessment (HRA) are increasingly linked to management decisions and actions in a strategic options assessment mode (Morris et al. 2006). While many of these methods are advanced, e.g. in epidemiological risk analysis, others are in an emergent stage. In the context of floods, there is a need to combine and align these analytical methodologies with those in other and fields such as hydrological risk and uncertainty analysis and technical safety and reliability analysis (De Moel and Aerts 2011). Key additions in our case were found to be perceived risks, health as a holistic process in welfare, action preferences and behavioural choices, socioeconomic and political conditions and impacts, risk compensation measures and the multiplicity of decision criteria (Fig. 4).

\subsection{Multi-actor governance and stakeholder participation}

Flood risk management is a complex field which involves a multitude of stakeholders and other actors with various 


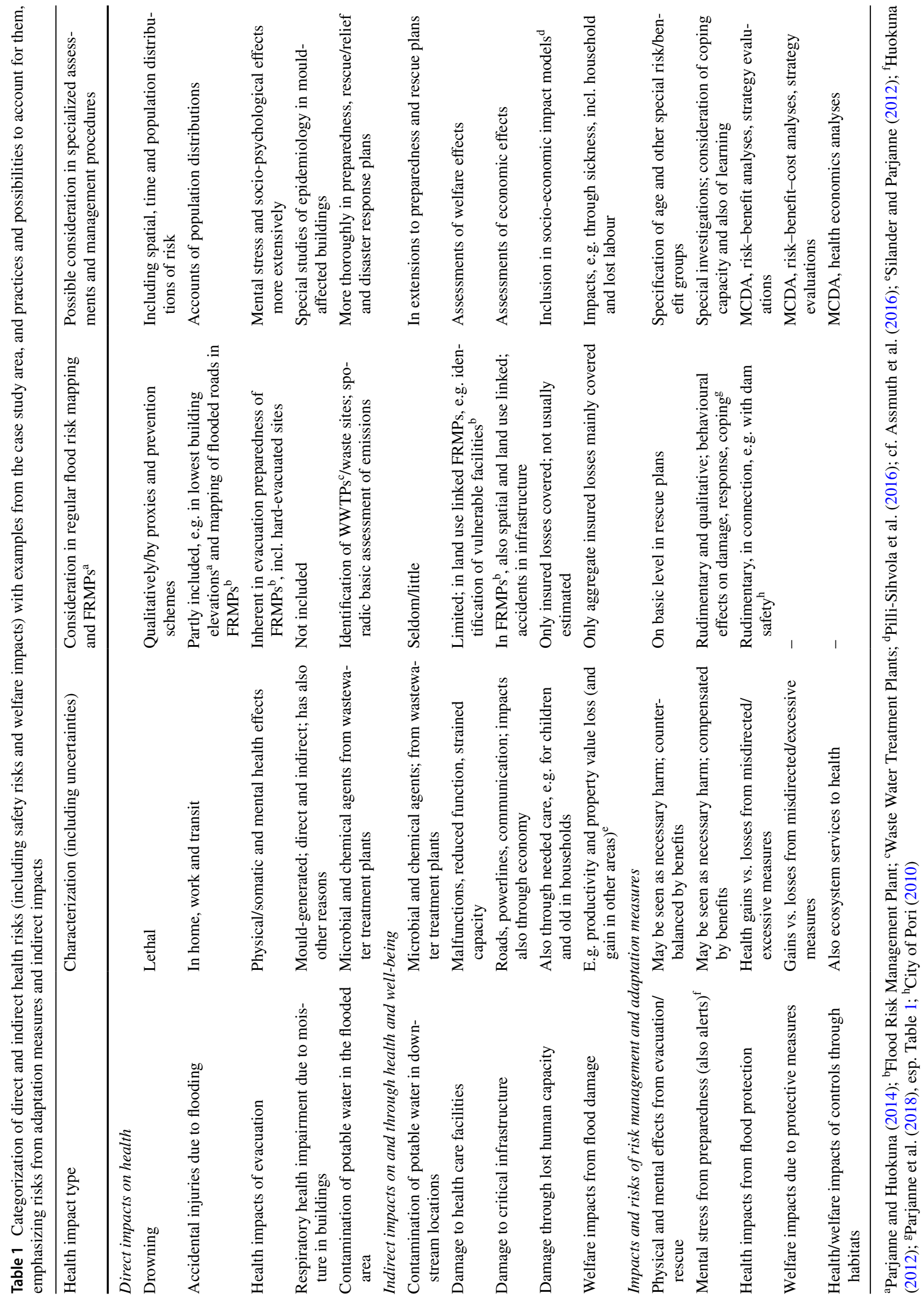




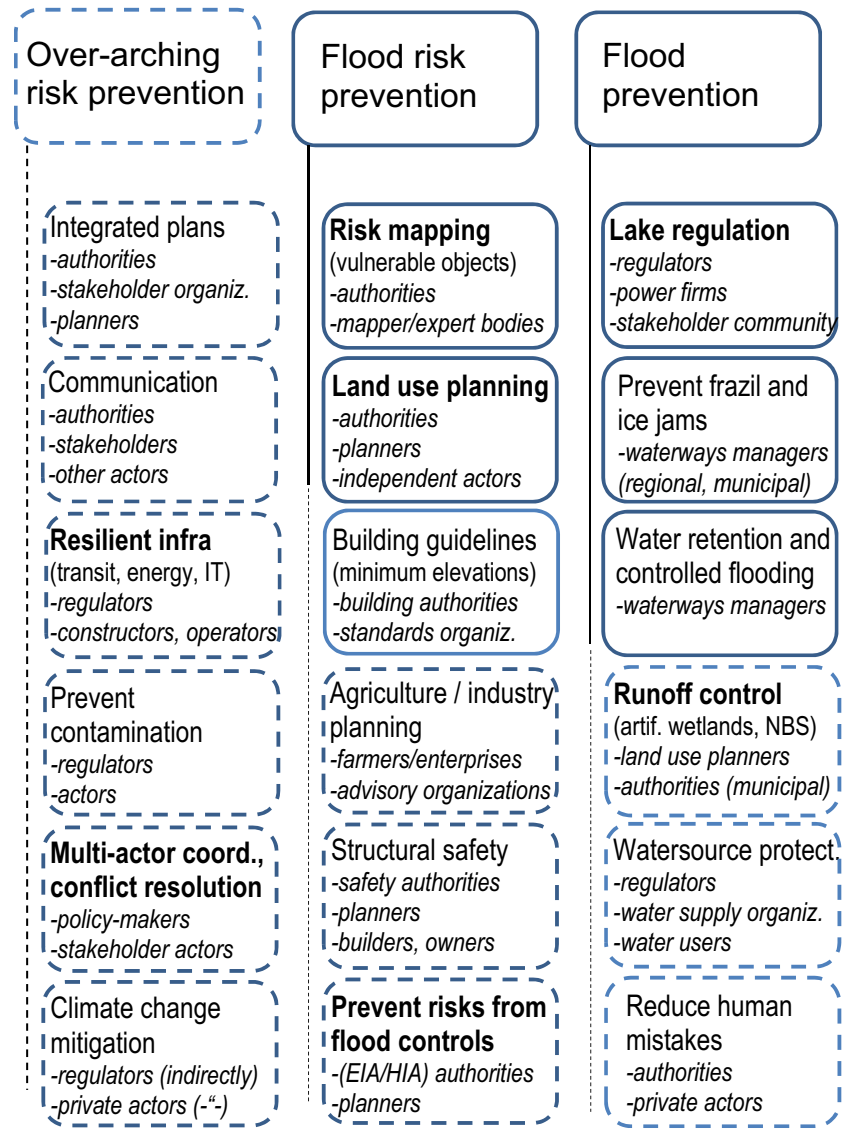

Fig. 4 An extended approach to flood risks in integrated governance, with previously proposed (Verta and Triipponen 2011; VARELY 2015) and identifiable new elements (hatched boxes) of flood risk management in the Kokemäenjoki river basin, emphasizing health risks, adjacent sectors, management cycles and adaptation. Suggested

positions, interests and views (Bruine de Bruin et al. 2014). The needs for extended and integrated multi-sector and multi-actor governance have been increased by climate change and by developments in society, e.g. regarding more responsive roles of the public sector and interactive means of communication, as reflected in national Finnish strategies (MoLE 2016, 2017) and also in the case study area (Söderholm et al. 2018). It is important that all relevant actors are able to genuinely participate in policy formulation, decisionmaking and action and in related deliberations. At the same time, challenges and opportunities for the various sectors and actors have also to be identified (Haapala and Johansson 2012). Thus, there is an obvious need to combine integrated and specific framings and approaches.

Some multi-actor governance has taken place in Finland within flood control and watercourse management based on established legislation, institutions and procedures, mainly those in water and safety (rescue) sectors (cf. 3.1). The key actors include Regional Centres for Economic Development, Transport and the Environment, regional rescue authorities

\begin{tabular}{|c|c|c|}
\hline $\begin{array}{l}\text { Flood } \\
\text { protection }\end{array}$ & Preparedness & Flood risk \\
\hline $\begin{array}{l}\text { Dredging } \\
\text {-waterways managers } \\
\text {-contractors }\end{array}$ & $\begin{array}{l}\text { Forecast / warning } \\
\text {-flood / meteorol. } \\
\text { expert organizations }\end{array}$ & $\begin{array}{l}\text { ood insurance } \\
\text { gulators } \\
\text { surers }\end{array}$ \\
\hline $\begin{array}{l}\text { River channeling } \\
\text {-waterways managers } \\
\text { and constructors }\end{array}$ & $\begin{array}{l}\text { Rehearsals } \\
\text {-rescue organizations } \\
\text {-volunteers }\end{array}$ & $\begin{array}{l}\text { Loss compen- } \\
\text { sation / recovery }\end{array}$ \\
\hline $\begin{array}{l}\text { Dams, pump stations } \\
\text {-water/land constructors }\end{array}$ & $\begin{array}{l}\text { Public information } \\
\text {-authorities } \\
\text {-media }\end{array}$ & $\begin{array}{l}\text {-subsidy organiz. } \\
\text { Burden-sharing / }\end{array}$ \\
\hline $\begin{array}{l}\text { Ice blasting / sawing } \\
\text { / ramming / booming } \\
\text {-water managers } \\
\text {-icebreakers, pioneers }\end{array}$ & $\begin{array}{l}\text { Rescue / relief plans } \\
\text {-rescue organizations } \\
\text {-social authorities }\end{array}$ & $\begin{array}{l}\text { I Burden-Snaring } \\
\text { I relief work } \\
\text { I -public organizations } \\
\text { - }- \text {-voluntary organiz. }\end{array}$ \\
\hline $\begin{array}{l}\text { Property protection } \\
\text {-rescue authorities } \\
\text {-builders, owners }\end{array}$ & $\begin{array}{l}\text { Temporary protect- } \\
\text { ion structures } \\
\text {-rescue organizations }\end{array}$ & $\begin{array}{l}\text { Recovery and copind } \\
\text { support } \\
\text {-health/welfare author. }\end{array}$ \\
\hline $\begin{array}{l}\text { IEvacuation } \\
\text { I-rescue org./authorities } \\
\text { I-evacuees } \\
\text { I-volunteers } \\
\text { 'Reduce } \\
\text { I } \\
\text { I vulnerability } \\
\text { I-social authorities } \\
\text { I-private actors }\end{array}$ & 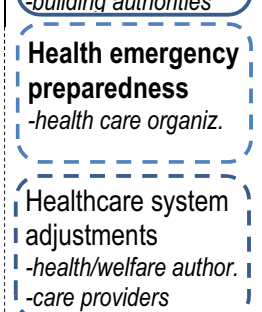 & $\begin{array}{l}\text { I Funding, cobenefit } \\
\text { l utilization } \\
\text {-public financing } \\
\text {-private funders } \\
--=- \\
\text { Conflict resolution } \\
\text {-policy-makers } \\
\text {-stakeholder actors }\end{array}$ \\
\hline
\end{tabular}

principal actors have been shown, and key areas of risk management and governance are indicated by boldface. Note the different levels (natural, technical, social) of risk management. NBS Nature-based solutions, EIA environmental impact assessment, HIA health impacts assessment, org./organiz. organizations, author./authorit. authorities

and municipalities, all of these having defined responsibilities and competences (Fig. 4). Also, citizens in impacted areas have been involved, e.g. in hearings and, more recently, EIA processes (Rajala 2013). However, participation is still often dominated by official bodies such as authorities, and stakeholders such as power industry and others with strong economic interests. Participation is also often restricted in the horizontal dimension between sectors, although coordination of their policies and activities is increasingly needed and also attempted. While EIA procedures are statutory in flood risk management, similar separate and detailed consequence analyses have not been required for Health Impact Assessment or Social Impact Assessment.

For the case area, as an important unofficial body for watercourse regulation, the monitoring group for watercourse regulation of the province of Pirkanmaa functioned largely as a discussion forum. This group has been transformed in 2017 to a more general-purpose collaboration group for water management (SYKE 2019f). Thus, multilevel, multi-sector and multi-actor (and multi-functional) 
governance structures, mechanisms and processes are gradually developing. However, different understandings and views as well as structural factors and inertia may hamper risk management, also preparedness. The creation of consensus views and new practices is related to the historical development of flood risk management, involving responses to high-risk events.

Stakeholder participation in flood risk management was studied by Söderholm et al. (2018) in the Kokemäenjoki river basin. Participatory and coordinative elements are included in flood risk management within spatial planning also in local areas (City of Pori 2008). Such approaches are becoming more common in related fields such as civil safety, particularly rescue services and disaster preparedness (Lehtonen 2006; Raivio 2006; Huokuna 2012). Citizen groups and organizations have been engaged also in opposition to flood protection solutions such as embankments, channels and dredging operations, due to concerns for adverse impacts (Rajala 2013, 66). On the other hand, it is evident that the concerns as well as the behavioural patterns and functional capabilities of citizens, especially those exposed to floods in the area, are often crucial for risk management and as such need to be accounted for (Lehtoranta et al. 2016).

\section{Discussion}

\subsection{Extended approaches to managing and governing flood risks and health}

It is evident from the case that flood risks need to be assessed more extensively and in a holistic manner. In many contexts, they have been considered fleetingly (e.g. Hassi and Rytkönen 2005). Adaptive flood risk management has developed especially in connection with climate change, in the case study area (Dubrovin et al. 2017a; Söderholm et al. 2018) and in all Finnish watercourses (Dubrovin 2015). Needs for extensions arise from new drivers and impacts, from increasingly complex problems and solutions, involving several actors, and from public and private expectations and demands (Benson et al. 2015; Klein 2016; cf. IRGC 2009). Health aspects of floods, and of extreme weather events and natural disasters in general, present particularly complex challenges to existing systems of governance, both within health care and in adjacent areas such as building and infrastructure (Bardy and Parrukoski 2010; MoI 2019).

Concepts of and approaches to health need to be extended to cover better the various aspects of health and well-being, including mental and social dimensions and outcomes (Greene et al. 2015; Lamond et al. 2015), the benefits from health promotion and from disease prevention, the distributions of health risks and benefits among particular groups
(Jimenez et al. 2013) and the capacities of communities to ensure health and well-being (Meyer et al. 2018) along with the attainment of other goals in the context of flood risks. Such extensions call for a broad, integrative and active notion of health, which is to be carried over to risk governance deliberations and interventions.

There are positive and negative consequences from flood control and also from more extensive and participatory management. The balancing of benefits and costs, regionally, among victims and beneficiaries and over time, is a key challenge in deliberation and action in some ways especially for health risks (Houghton and Castillo-Salgado 2017). Important synergies and co-benefits exist between management areas and policy sectors (EEA 2016). The choice of (combinations of) strategies and measures depends on the case and on the valuation of outcomes (and of processes), and these in turn depend on stakeholder perceptions and views. Thus, often clear-cut best solutions cannot be found, and traditional utility-maximizing optimization falls short (Woodward et al. 2014). Heuristic approaches encompassing the variability and evolution of views through participation have advantages, e.g. in education and social learning (Meyer et al. 2018). It seems natural to combine such heuristic methods with quantitative and formal decision support systems.

An extended approach to risk management is also needed, covering its stages, options and consequences more fully and in an adaptive and active mode (IRGC 2009; Prutsch et al. 2014). In water regulation, extensions and developments have already been undertaken (Dubrovin 2015). Cost-benefit analyses can be made of extreme events (Virta et al. 2011) but quantification is difficult. Building resilience in technological, natural and social terms is key (Gallopin 2006; Bosher et al. 2009; Mudombi 2018; Pearson et al. 2018). In the case of health aspects of flood risk management in the context of adaptation to climate change, many additional types and classes of options can be discerned (Fig. 4). There is thus continuous need to improve the coordination between policies and strategies (Mickwitz et al. 2009; EEA 2016). As part of such extended approaches to risk governance, deliberation on scenarios could be developed to cover both natural and social or technological factors of hazard and vulnerability, as well as strategic and technical options. Such experimentation could be linked with risk communication (McCarthy et al. 2007; Perrels et al. 2008), learning activities (Viglione et al. 2014) and resilience development (Pearson et al. 2018).

The scale of risks and of their management is crucial, as shown in our case by the need to integrate upstream and downstream solutions and, more generally, various levels of policies and strategies. The appropriate modes of governance and management procedures also vary between regions (Biesbroek et al. 2010; Lumbroso et al., 2011). Thus, 
adaptive multi-level, multi-sector and multi-actor (including civil society actors) governance and management are needed (Fig. 4), especially as the tasks grow more extensive and complex (Assmuth et al. 2009, 2010; Keune and Assmuth 2018). Regional strategies and systems are important (Haanpää et al. 2009), and river basins constitute a natural entity with regard to floods. However, governance has to be mainstreamed also on municipal level (Næss et al. 2005). The collaboration between municipal and regional authorities (mainly environmental, economic, transport and safety) builds a core, but additional sectors and actors need to be included.

\subsection{Knowledge for adaptive and systemic participatory risk governance}

Information of many kinds is needed for decisions and actions on floods (Månsson 2019). In addition to definite and quantitative information, many issues in flood risk management require qualitative, reflective, experiential, lay, local and traditional knowledge. 'Hard' knowledge is obtained by models and analyses, in interaction with observation and other empirical means. In health care, clinical examinations and reports are a key source of information, including perceived or feared impacts. These can complement each other in joint fact-finding and knowledge brokering involving the deliberation on values, especially for adaptive governance where dynamically evolving and pluralistic notions and framings are central (Michaels 2009; Saarela et al. 2015), and in multi-directional transfer and co-production of knowledge (Liu et al. 2012). Similarly in flood risk management, multi-criteria analyses provide important tools to address pluralistic notions and values, also in management of the case study watercourse (Marttunen 2011). The consideration of risk perceptions, mental health impacts and socio-cultural aspects of adaptation, including trust, requires knowledge that extends beyond the objectively measurable (Wesselink and Warner 2010; Viglione et al. 2014).

With variable and unexpected phenomena such as floods, uncertainties hamper knowledge generation and action. New levels of uncertainty are added by the case dependency of health impacts (Parjanne et al. 2018); the element of surprise (Merz et al. 2015), the complex repercussions of floods within health and welfare due also to behavioural factors, the connectedness of impacts and actions, and the subjective and evaluative aspects. These constrain modelling, formal decision analyses such as event trees (Cherqui et al. 2015) and quasi-objective knowledge (Leskens et al. 2014). As stressed by Söderholm et al. (2018), the assessment of risks of exceptional floods is particularly uncertain as there are not enough empirical data to build on. Many facts in social and economic domains are also highly uncertain, but are also more easily accepted as such. Multi-criteria methods (Zagonari and Rossi 2013), participatory deliberation, and adaptive and also experimental risk governance are thus needed. The "translational discourse" of Faulkner et al. (2007) between scientists, practitioners and publics is a key part of such adaptive participatory governance. Flood and health risk experts need to interact with other parties in order to co-produce knowledge (Landström et al. 2011), but participatory deliberation is needed also for co-usage of knowledge in action.

With the management of flood risks, timely forecasts and information are crucial, as events and responses often develop rapidly. Assessment methods should allow rapid acquisition, processing and use of relevant information to steer action. Presently, there is often a mismatch of flood models and strategic decisions (Leskens et al. 2014). Surveillance is a key part of risk management and needs to include many types of monitoring, from environmental and health states to human responses, utilizing ensembles of decision support systems (Demeritt et al. 2010). Updating of information is needed for adaptive governance. On the other hand, knowledge is generated over long time scales, e.g. when using accumulated hydrological and health data. Both approaches have been developed also for the case study area (SYKE 2019b, e).

The ascertainment of causality is challenging with multi-factorial and multi-attribute health conditions or processes and with indirect impacts and risks. They are hard to attribute to causes (such as climate change) at the level of certainty routinely required in evidence-based medicine. Responses need to account for this unattributability along with other uncertainties and characteristics of floods, e.g. in insurance (FFFS 2014). Consequently, also the focus in health impact assessment and planning may need to shift, e.g. from prevalence to vulnerability (Dogra et al. 2019).

Broad and integrated knowledge on floods, their impacts and risks and their management is needed (Månsson 2019). Information sources and methods in a variety of fields thus have to be combined, including flood risk mapping and assessment models and operative decision support systems. These should increasingly include health, linked to water and environmental management and to technical and civil safety. This integration is proceeding in many applied areas such as land use and water resource planning (notably based on the EU's overarching Water Framework Directive in combination with the Floods Directive), in climate adaptation, in other areas of planning, in socio-economic assessment and in systems and safety analysis. In such contexts, also knowledge is integrated between levels of governance, top-down and bottom-up (Priest et al. 2016). An important part of this integration is the use of interactive and inclusive health 
impact and risk assessment methods in other areas, and vice versa.

\section{Conclusions and recommendations}

Based on the above analyses, we formulate the following general conclusions and recommendations:

- Risk assessment and management of floods in Finland as elsewhere are under dynamic development especially under climate change, whereby new issues and approaches are incorporated to traditional flood control.

- There are clear needs and opportunities to broaden perspectives and methods and include non-technical and qualitative aspects; societal dimensions (e.g. risk perception, communication, compensation and governance), indirect factors and consequences of floods (e.g. macroeconomics beyond the area); over-arching prevention; and counter-veiling risks of management (avoiding maladaptation and loss of systemic resilience)

- There is improved understanding of flood risks with regard to health, and of its links and synergies with other areas such as safety. There is also evolving consensus on related goals in risk management, but also obstacles for their implementation. These include divergent interests of stakeholders and of sector policies. As such, the case provides an example of challenges in climate policy mainstreaming and in adaptive governance.

- Communication, deliberation and collaboration are found to be crucial in adaptive multi-actor governance of health risks from floods. They involve the collective resolution of appropriate balances of risks and impacts among populations, regions and periods, and the negotiation of competing and complementary interests.

- Knowledge plays a key role in developing extensive and efficient, integrated and adaptive flood risk assessment and management and can be based on improved framing, models and data of risks, impacts and options. However, knowledge is uncertain, imperfect, changing and valuedladen, calling for inter-disciplinary and heuristic methods, flexible procedures combining simplification with specification and pluralistic knowledge co-generation.

Acknowledgements Open access funding provided by Finnish Environment Institute (SYKE). This work has been supported by, besides our employers, the Academy of Finland on the projects CONPAT (Aquatic Contaminants-Pathways, Health Risks and Management) and ClimWater (Climate Change and Water Cycle: Effect to Water Resources and their Utilization in Finland). This study was initiated in connection with the European Topic Centre Climate Change
Adaptation of the European Environment Agency. The responsibility for the information and the views presented lies with the authors. We thank Dr. Noora Veijalainen and two anonymous reviewers for helpful comments, Turo Hjerppe for providing a map of the river basin and Mikko Sane for providing flood maps.

Open Access This article is distributed under the terms of the Creative Commons Attribution 4.0 International License (http://creativeco mmons.org/licenses/by/4.0/), which permits unrestricted use, distribution, and reproduction in any medium, provided you give appropriate credit to the original author(s) and the source, provide a link to the Creative Commons license, and indicate if changes were made.

\section{References}

Aaltonen J, Veijalainen N, Huokuna M (2010) The effect of climate chance on frazil ice jam formation in the Kokemäenjoki River. In: 20th IAHR international symposium on ice

Alho P, Sane M, Huokuna M, Käyhkö J, Lotsari E, Lehtiö L (2008) Tulvariskien kartoittaminen [Mapping of flood risks, in Finnish]). Environmental Administration guidelines 2/2008. Finnish Environment Institute, Helsinki and University of Turku, Turku

Antonovsky A (1996) The salutogenic model as a theory to guide health promotion. Health Promotion Int 11:11-18

Assmuth T, Hildén M (2008) The significance of information frameworks in integrated risk assessment and management. Environ Sci Pol 11:71-86. https://doi.org/10.1016/j.envsci.2007.07.006

Assmuth T et al (2009) Big pictures, close-ups, roadmaps and mind-maps: perspectives on integrated treatment of multiple risks. Int J Risk Assess Mgmt 13(3-4):294-312. https://doi. org/10.1504/IJRAM.2009.030701

Assmuth T et al (2010) Integrated risk assessment and risk governance as socio-political phenomena: a synthetic view of the challenges. Sci Total Environ 408:3943-3953. https://doi. org/10.1016/j.scitotenv.2009.11.034

Assmuth $\mathrm{T}$ et al (2016) Integrated frameworks for assessing and managing health risks in the context of artificial groundwater recharge with river water. Integr Environ Assess Manage 12(1):160-173. https://doi.org/10.1002/ieam.1660

Azuma K, Ikeda K, Kagi N, Yanagi U, Hasegawa K, Osawa H (2014) Effects of water-damaged homes after flooding: health status of the residents and the environmental risk factors. Int J Environ Health Res 24(2):158-175. https://doi.org/10.1080/09603 123.2013.800964

Bardy M, Parrukoski S (eds) (2010) Hyvinvointi ilmastonmuutoksen oloissa? Keskustelunavauksia tulevaisuusvaliokunnalle [Welfare under conditions of climate change? Discussion points for the Committee on Future, in Finnish]. National Institute for Publish Health and Welfare (THL), Helsinki

Borràs-Santos A, Jacobs JH, Täubel M, Haverinen-Shaughnessy U, Krop EJ, Huttunen K, Hirvonen MR, Pekkanen J, Heederik DJ, Zock JP, Hyvärinen A (2013) Dampness and mould in schools and respiratory symptoms in children: the HITEA study. Occup Environ Med 70(10):681-687. https://doi.org/10.1136/oemed $-2012-101286$

Benson D, Lorenzoni I, Cook H (2015) Evaluating social learning in England flood risk management: an 'individual-community interaction' perspective. Environ Sci Pol 55(2):326-334. https ://doi.org/10.1016/j.envsci.2015.05.013

Biesbroek GR, Swart RJ, Carter TR, Coan C, Henrichs T, Mela H, Morecroft MD, Rey D (2010) Europe adapts to climate change: 
comparing national adaptation strategies. Global Environ Change 20(3):440-450. https://doi.org/10.1016/j.gloenvcha.2010.03.005

Bosher LS, Dainty ARJ, Carrillo PM, Glass J, Price ADF (2009) Attaining improved resilience to floods: a proactive multistakeholder approach. Disaster Prev Manag 18(1):9-22. https ://doi.org/10.1108/09653560910938501

Bouzid M, Hooper L, Hunter PR (2013) The effectiveness of public health interventions to reduce the health impact of climate change: a systematic review of systematic reviews. PLoS ONE 8(4):e62041. https://doi.org/10.1371/journal.pone.0062041

Briggs DJ (2008) A framework for integrated environmental health impact assessment of systemic risks. Environ Health 7(61):117. https://doi.org/10.1186/1476-069X-7-61

Bruine de Bruin W et al (2014) Public perceptions of local flood risk and the role of climate change. Environ Syst Decis 34(4):591599. https://doi.org/10.1007/s10669-014-9513-6

Cherqui F, Belmeziti A, Granger D, Sourdril A, Le Gauffre P (2015) Assessing urban potential flooding risk and identifying effective risk-reduction measures. Sci Total Environ 514:418-425. https ://doi.org/10.1016/j.scitotenv.2015.02.027

City of Pori (2008) PORI. Kantakaupungin yleiskaava 2025 [PORI. General plan for the inner city to 2025, in Finnish]. Porin kaupunkisuunnittelusarja/City planning series of Pori C63/2008. City of Pori, Pori

City of Pori (2009) Porin kaupunkitulva 12.8.2007 loppuraportti. [Urban flood in the City of Pori 12.8.2007. Final report, in Finnish] Porin kaupungin tekninen palvelukeskus/Technical Service Center, Pori

City of Pori (2010) Porin tulvasuojelupadot. Vahingonvaarasevitys. [The flood protection dams in Pori. Survey of loss danger, in Finnish] Updated 12.2.2010. Porin kaupungin tekninen palvelukeskus/Technical Service Center, Pori. (accepted in March 252010 by Häme Regional Center for Economic Development, Transport and the Environment.)

CRED (2015) The human cost of natural disasters - a global perspective. Centre for Research on the Epidemiology of Disasters, Brussels

Dawson RJ, Thompson D, Johns D, Wood R, Darch G, Chapman L, Hughes PN, Watson GWR, Paulson K, Bell S, Gosling SN, Powrie W, Hall JW (2018) A systems framework for national assessment of climate risks to infrastructure. Philos Trans A Math Phys Eng Sci 376(2121):20170298. https://doi.org/10.1098/ rsta.2017.0298

De Moel H, Aerts J (2011) Effect of uncertainty in land use, damage models and inundation depth on flood damage estimates. Nat Hazards 58(1):407-425

Demeritt D et al (2010) Challenges in communicating and using ensembles in operational flood forecasting. Meteorol Appl 17(2):209-222

Dogra N, Kakde V, Taneja P (2019) Decision tool for climate disasters and infectious disease at sub-national level in India: ensuring a paradigm shift in health planning from prevalence to vulnerability. Acta Trop 191:60-68. https://doi.org/10.1016/j.actatropic a.2018.12.006

Dubrovin T (2015) Sopeutumistarve ilmastonmuutokseen vesistöjen säännöstelyssä [Climate change adaptation needs in watercourse regulation, in Finnish]. Suomen ympäriatökeskus, Helsinki 26.6.2015

Dubrovin T, Jakkila J, Aaltonen J, Kumpumäki M, Vehviläinen B (2017) Kokemäenjoen vesistöalueen padotus- ja juoksutusselvitys [Assessment of backwater and drainage in the Kokemäenjoki river basin, in Finnish]. Finnish Environment Institute, Helsinki, p 41

Dubrovin T, Isid D, Kumpumäki M, Mustajoki J, Jakkila J, Marttunen M (2017b) Kehittämissuositukset Pirkanmaan keskeisten järvien säännöstelyille. [Development recommendations for the regulation of the central lakes in the Pirkanmaa region, in Finnish]. Pirkanmaan elinkeino-, liikenne- ja ympäristökeskus/ Pirkanmaa Regional Centre for Economic Development, Transport and the Environment, Tampere. Raportteja/Reports 26/2017

EEA (2010) Mapping the impacts of natural hazards and technological accidents in Europe. An overview of the last decade. European Environment Agency, Copenhagen. EEA Technical report no. $13 / 2010$

EEA (2016) Flood risks and environmental vulnerability. Exploring the synergies between floodplain restoration, water policies and thematic policies. EEA report no. 1/2016. European Environment Agency, Copenhagen

EP \& EC (2007) DIRECTIVE 2007/60/EC on the assessment and management of flood risks [Floods Directive]. The European Parliament and The Council of the European Union, Brussels. EU J. L 288/27. 6.11.2007

Faulkner H, Parker D, Green C, Beven K (2007) Developing a translational discourse to communicate uncertainty in flood risk between science and the practitioner. Ambio 36(8):692-703. https://doi.org/10.1579/0044-7447(2007)36[692:DATDT C]2.0.CO;2

FFFS (2014) Kysymyksiä ja vastauksia: Poikkeuksellisten tulvavahinkojen korvaaminen muuttuu 2014 [Q\&A: Compensation for exceptional flood damage will change in 2014, in Finnish] Federation of Finnish Financial Services, Helsinki. 2 p.

Finkel A (2011) "Solution-focused risk assessment": a proposal for the fusion of environmental analysis and action. Hum Ecol Risk Assess Int J 17(4):754-787

Finnish Cabinet (1994) Asetus ympäristövaikutusten arviointimenettelystä [Regulation of the cabinet environmental impact assessment, in Finnish and Swedish] Cabinet of Finland, Helsinki. § 7. AsK 792/1994.

Finnish Cabinet (2010) Valtioneuvoston asetus tulvariskien hallinnasta (659/2010) [Regulation of the cabinet on flood risk management, in Finnish] Cabinet of Finland, Helsinki

Finnish Parliament (1984) Patoturvallisuuslaki [Dam Safety Act, in Finnish and Swedish]. Finnish Parliament, Helsinki. As.K. 1.6.1984 N:o 413.

Finnish Parliament (1994) Laki ympäristövaikutusten arviointimenettelystä [Environmental Impact Assessment Act, in Finnish and Swedish] Finnish Parliament, Helsinki. §§ 1-2, 4, 6, 9-13, 26. AsK 468/1994

Finnish Parliament (2010) Laki tulvariskien hallinnasta (620/2010) [Flood Risk Management Act (620/2010), in Finnish and Swedish] Finnish Parliament, Helsinki

Finnish Parliament (2011) Pelastuslaki, $14 \S$ (379/2011) [Rescue Act, in Finnish and Swedish] Finnish Parliament, Helsinki

Finnish Parliament (2015) Ilmastolaki (609/2015) [Climate Act, in Finnish and Swedish] Finnish Paliament, Helsinki

Gallopin G (2006) Linkages between vulnerability, resilience and adaptive capacity. Global Environ Change 16(3):293-303

Greene G, Paranjothy S, Palmer SR (2015) Resilience and vulnerability to the psychological harm from flooding: the role of social cohesion. Am J Public Health 105(9):1792-1795. https ://doi.org/10.2105/AJPH.2015.302709

Haahtela $\mathrm{T}$ et al (WAO Special Committee on Climate Change and Biodiversity) (2013) The biodiversity hypothesis and allergic disease: world allergy organization position statement. World Allergy Org J 6(3):1-18

Haanpää S, Tuusa R, Peltonen L (2009) Ilmastonmuutoksen alueelliset sopeutumisstrategiat. READNET-hankkeen loppuraportti. [Regional adaptation strategies to climate change. Final report of the READNET project, in Finnish] Aalto University of Technology, Espoo. Research and Education Centre for Community Planning Report C75 
Haapala J, Johansson M (2012) Itämeri. (Baltic Sea, in Finnish) In: Ruuhela R (ed) Miten väistämättömään ilmastonmuutokseen voidaan varautua? - yhteenveto suomalaisesta sopeutumistutkimuksesta eri toimialoilla [How to adapt to the unavoidable climate change?-Summary of Finnish adaptation research in various sectors, in Finnish] Ministry of Agriculture and Forestry, Helsinki. Maa- ja metsätalousministeriön julkaisuja 6/2011: 24-27

Hassi J, Rytkönen M (2005) Climate warming and health adaptation in Finland. FINADAPT working paper 7. Finnish Environment Institute, Helsinki. Finnish Environment Institute Mimeographs 337

Helama S, Holopainen J, Partonen T (2013) Temperature-associated suicide mortality: contrasting roles of climatic warming and the suicide prevention program in Finland. Environ Health Prev Med 18:349-355. https://doi.org/10.1007/s12199-013-0329-7

Hildén M, Groundstroem F, Carter TR, Halonen M, Perrels A, Gregow H (2016) Ilmastonmuutoksen heijastevaikutukset Suomeen [Crossborder impacts of climate change on Finland, in Finnish]. Prime Minister's Office, Helsinki. Valtioneuvoston selvitys- ja tutkimustoiminnan julkaisusarja 46/2016

Houghton A, Castillo-Salgado C (2017) Health co-benefits of green building design strategies and community resilience to urban flooding: a systematic review of the evidence. Int J Environ Res Public Health. https://doi.org/10.3390/ijerph14121519

Huokuna M (2012) Tulvariskeihin varautuminen [Preparedness for flood risks, in Finnish] Ilmatieteen laitos Helsinki. Ilmastokatsaus/Climate Surv 10(2012):8-9

IRGC (2005) White paper on risk governance: towards an integrative approach. International Risk Governance Council, Geneva

IRGC (2009) Risk Governance deficits. An analysis and illustration of the most common deficits in risk governance. International Risk Governance Council, Geneva

Jimenez AM, Collins TW, Grineski SE (2013) Intra-ethnic disparities in respiratory health problems among Hispanic residents impacted by a flood. J Asthma 50(5):463-471. https://doi. org/10.3109/02770903.2013.786087

Johanning E, Auger P, Morey PR, Yang CS, Olmsted E (2014) Review of health hazards and prevention measures for response and recovery workers and volunteers after natural disasters, flooding, and water damage: mold and dampness. Environ Health Prev Med 19(2):93-99. https://doi.org/10.1007/s12199-013-0368-0

Juntunen J, Meriläinen P, Simola A (2017) Public health and economic risk assessment of waterborne contaminants and pathogens in Finland. Sci Total Environ. 599-600:873-882. https://doi. org/10.1016/j.scitotenv.2017.05.007

Karvonen A, Rintamäki P, Jokela J, Valtonen T (2010) Increasing water temperature and disease risks in aquatic systems: climate change increases the risk of some, but not all, diseases. Int J Parasitol 40:1483-1488

Keune H, Assmuth T (2018) Framing complexity in human health and the environment. Oxford research encyclopedia of environmental science. USA: Oxford University Press. https://doi.org/10.1093/ acrefore/9780199389414.013.350

Kiljn F, Kreibich H, deMoel H, Penning-Rowsell E (2015) Adaptive flood risk management planning based on a comprehensive flood risk conceptualization. Mitig Adapt Strateg Glob Chang 20(6):845-864. https://doi.org/10.1007/s11027-015-9638-z

Klein J (2016) Embeddedness of climate change adaptation: established procedures and contending discourses for flood protection in Espoo, Finland. Local Environ 21(2):254-271

Koks EE, Bočkarjova M, de Moel H, Aerts JC (2015) Integrated direct and indirect flood risk modeling: development and sensitivity analysis. Risk Anal. 35(5):882-900. https://doi.org/10.1111/ risa. 12300
Koskinen M (ed) (2006) Porin tulvat — hallittuja riskejä? [Floods in Pori-controlled risks? [in Finnish] Regional Environment Centre of South-Western Finland, Turku. Suomen Ympäristö/The Finnish Environment 19

Laaksonen S, Pusenius J, Kumpula J, Venäläinen A, Kortet R, Oksanen A, Hoberg E (2010) Climate change promotes the emergence of serious disease outbreaks of Filarioid nematodes. EcoHealth 7:7-13. https://doi.org/10.1007/s10393-010-0308-z

Lamond JE, Joseph RD, Proverbs DG (2015) An exploration of factors affecting the long term psychological impact and deterioration of mental health in flooded households. Environ Res 140:325-334. https://doi.org/10.1016/j.envres.2015.04.008

Landeg O, Whitman G, Walker-Springett K, Butler C, Bone A, Kovats S (2019) Coastal flooding and frontline health care services: challenges for flood risk resilience in the English health care system. J Health Serv Res Policy. https://doi.org/10.1177/13558 19619840672

Landström C, Whatmore SJ, Lane SN, Odoni NA, Ward N, Bradley $S$ (2011) Coproducing flood risk knowledge: redistributing expertise in critical 'participatory modelling'. Environ Plan A 43:1617-1633. https://doi.org/10.1068/a43482

Lane K, Charles-Guzman K, Wheeler K, Abid Z, Graber N, Matte T (2013) Health effects of coastal storms and flooding in urban areas: a review and vulnerability assessment. J Environ Public Health 2013:913064. https://doi.org/10.1155/2013/913064

Lehtonen J (2006) Rescue services in regional development: accessibility of Länsi-Uusimaa Department for Rescue Services. M.A. thesis, University of Helsinki Department of Geography, Helsinki. 87 p.

Lehtoranta V, Väisänen S, Rytkönen A-M (2016) Huittisten, Lapväärtin ja Kalajoen alueiden kotitalouksien näkemykset tulvariskien hallinnasta [The opinions of household in the Huittinen, Lapväärti and Kalajoki areas about flood risk management, in Finnish]. Finnish Environment Institute, Helsinki

Leppo K, Ollila E, Peña S, Wismar M, Cook S (eds) (2013) Health in all policies. Seizing opportunities, implementing policies. Ministry of Social Affairs and Health, Helsinki

Leskens JG, Brugnach M, Hoekstra AY, Schuurmans W (2014) Why are decisions in flood disaster management so poorly supported by information from flood models? Environ Model Softw 53(4):53-61

Liu H-Y, Bartonova A, Panagiotis N, Yang A, Kobernus MJ, Negrenti E, Houiadas C (2012) Facilitating knowledge transfer: decision support tools in environment and health. Environ Health 11(Suppl 1):S17

Lonka H, Nikula J (2008) Maankäyttö ja kuntatekninen suunnittelu taajamien tulvariskien hallinnassa [Land use and planning for municipal engineering in managing flood risks in urban areas, in Finnish] Regional Environment Centre of South-Eastern Finland, Kouvola. Reports of Regional Environment Centre of South-Eastern Finland 1/2008

Lumbroso D, Stone K, Vinet F (2011) An assessment of flood emergency plans in England and Wales, France and the Netherlands. Nat Hazards 58(1):341-363

Lyytimäki J, Assmuth T (2015) Down with the flow: Public debates shaping the risk framing of artificial groundwater recharge. GeoJournal 80(1):113-127

Marttunen M (2011) Interactive multi-criteria decision analysis in the collaborative management of watercourses. Aalto University publication series Doctoral Dissertations 75/2011. Aalto University of Technology, Espoo

Marttunen M, Nieminen H, Keto A, Suomalainen M, Tarvainen A, Moilanen S, Järvinen EA (2004) Pirkanmaan keskeisten järvien säännöstelyjen kehittäminen - Yhteenveto ja suositukset [The development of regulation of the central lakes of Pirkanmaa region - Summary and recommendations, in Finnish]. 
Suomen ympäristö/Finnish Environment 689. Finnish Environment Institute, Helsinki

McCarthy S, Tunstall S, Parker D, Faulkner H, Howe J (2007) Risk communication in emergency response to a simulated extreme flood. Environ Hazards 7(3):179-192. https://doi. org/10.1016/j.envhaz.2007.06.003

McMichael WRE, Hales S (2006) Climate change and human health: present and future risks. Lancet 367(9513):859-869. https:// doi.org/10.1016/S0140-6736(06)68079-3

Merz B, Vorogushyn S, Lall U, Viglione A, Blöschl G (2015) Charting unknown waters-on the role of surprise in flood risk assessment and management. Water Resour Res S1(8):63996416. https://doi.org/10.1002/2015WR017464

Meyer M, Hendricks M, Newman G, Horney J, Berke P, Masterson J, Sansom G, Cousins T, Van Zandt S, Cooper J (2018) Participatory action research: tools for disaster resilience education. Int J Disaster Resil Built Environ 9(4-5):402-419. https://doi. org/10.1108/IJDRBE-02-2017-0015

Michaels S (2009) Matching knowledge brokering strategies to environmental policy problems and settings. Environ Sci Pol 12(7):994-1011

Mickwitz P, Aix F, Beck S, Carss D, Ferrand N, Görg C, Jensen A, Kivimaa P, Kuhlicke C, Kuindersma W, Máñez M, Melanen M, Monni S, Branth Pedersen A, Reinert H, van Bommel S (2009) Climate policy integration, coherence and governance. PEER report no. 2. Partnership for European Environmental Research (PEER), Helsinki

MoAF (2011) Maa- ja metsätalousministeriön ilmastonmuutokseen sopeutumisen toimintaohjelma 2011-2015 - Huoltovarmuutta, kestävää kilpailukykyä ja riskinhallintaa [Action program for adaptation to climate change of the Ministry of Agriculture and Forestry 2011-2015, in Finnish] Ministry of Agriculture and Forestry, Helsinki

MoE (2015) Ilmastotavoitteita edistävä kaavoitus [Spatial planning for climate goals, in Finnish]. Suomen ympäristö/Finnish Environment 3 | 2015. Ministry of the Environment, Helsinki

MoE (2017) Action plan for the adaptation to climate change of the environmental administration 2022. Reports of the Ministry of the Environment 25en I 2016. Ministry of the Environment, Helsinki

MoI (2016) A safe and resilient Finland-rescue services strategy 2025. Internal security 20/2016. Ministry of Interior, Helsinki

MoI (2019) National risk assessment 2018. Publications of the Ministry of the Interior 2019:9. Ministry of the Interior, Helsinki

Molarius R, Keränen J, Jylhä K, Sarlin T, Laitila A (2010) Suomen elintarviketurvallisuuden haasteita muuttuvassa ilmastossa [Challenges to Finnish food security in a changing climate, in Finnish]. VTT Tutkimusraportti/Research report VTT-R-267210. Finnish Institute for Technological Research (VTT), Espoo

MoLE (2016) Government report on the National Energy and Climate Strategy for 2030. Publications of the Ministry of Economic Affairs and Employment 12/2017. Ministry of Labor and Enterprise, Helsinki

MoLE (2017) Taustaraportti kansalliselle energia- ja ilmastostrategialle vuoteen 2030 [Background report for the national energy and climate strategy until 2030, in Finnish] Ministry of Labor and Enterprise, Helsinki. Updated 2.2.2017

Morris GP, Beck SA, Hanlon P, Robertson R (2006) Getting strategic about the environment and health. Public Health 120:889-907

Mudombi S (2018) Risk, resilience and adaptation to global change. In: Mensah P et al (eds) Systems analysis approach for complex global challenges. Springer, Cham, pp 41-61. https://doi. org/10.1007/978-3-319-71486-8_3

Månsson P (2019) Uncommon sense: a review of challenges and opportunities for aggregating disaster risk information. Int J Disaster Risk Reduct. https://doi.org/10.1016/j.ijdrr.2019.101149.
Mäntylä K, Saarelainen S (2008) Rakennetun ympäristön sopeutuminen ilmastonmuutoksen aiheuttamille tulvavaikutuksille [Adaptation of built environment to flood effects of climate change, in Finnish]. VTT Tutkimusraportti/Research report VTT-R-04429-08. Finnish Institute for Technological Research (VTT), Espoo

Næss LO, Bang G, Eriksen S, Vevatne J (2005) Institutional adaptation to climate change: flood responses at the municipal level in Norway. Glob Environ Chang 15(2):125-138. https://doi. org/10.1016/j.gloenvcha.2004.10.003

NBW (1984) Kokemäenjoen vesistön vesien käytön kokonaissuunnitelma: Integrated water resources development plan for the River Kokemäenjoki drainage basin. Vesihallituksen julkaisuja Publications of NBW no. 38. National Board of Waters, Helsinki

Näyhä S (2005) Environmental temperature and mortality. Int J Circumpolar Health 64(5):451-458

Olanrewaju CC, Chitakira M, Olanrewaju OO, Louw E (2019) Impacts of flood disasters in Nigeria: A critical evaluation of health implications and management. JAMBA 1:557. https:// doi.org/10.4102/jamba.v11i1.557

Pagano A, Pluchinotta I, Pengal P, Cokan B, Giordano R (2019) Engaging stakeholders in the assessment of NBS effectiveness in flood risk reduction: a participatory system dynamics model for benefits and co-benefits evaluation. Sci Total Environ 690:543-555. https://doi.org/10.1016/j.scitotenv.2019.07.059

Parjanne A, Marttunen M, Rytkönen A-M, Huokuna M (2012) Involvement of local stakeholders with multi-criteria decision analysis in flood risk management in Finland. Thematic Workshop on implementation of the Directive 2007/60/EC Bucharest, 17-19 April 2012

Parjanne A, Huokuna M (eds) (2014) Tulviin varautuminen rakentamisessa - Opas alimpien rakentamiskorkeuksien määrittämiseksi ranta-alueilla [Flood preparedness in building guide for determining the lowest building elevations in shore areas, in Finnish] Finnish Environment Institute, Helsinki. Ympäristöopas/Environment Guide I 2014

Parjanne A, Silander J, Tiitu M, Viinikka A (2018) Suomen tulvariskit nyt ja tulevaisuudessa. Varautuminen maankäytön, talouden ja ilmaston muutokseen [Finnish flood risks now and in the future. Preparedness for changes in land use, economy and climate, in Finnish] Finnish Environment Institute, Helsinki. Suomen ympäristökeskuksen raportteja/Reports of Finnish Environment Institute 30/2018

Parkes MW, Morrison KE, Bunch MJ, Hallström LK, Neudoerffer RC, Venema HD, Waltner-Toews D (2010) Towards integrated governance for water, health and social-ecological systems: the watershed governance prism. Global Environ Change 20(4):693-704

Pearson J, Punzo G, Mayfield M, Brighty G, Parsons A, Collins P, Jeavons S, Tagg A (2018) Flood resilience: consolidating knowledge between and within critical infrastructure sectors. Environ Syst Decis 38(3):318-329. https://doi.org/10.1007/ s10669-018-9709-2

Pellikka H, Leijala U, Johansson MM, Leinonen K, Kahma KK (2018) Future probabilities of coastal floods in Finland. Continental Shelf Res 57:32-42. https://doi.org/10.1016/j. csr.2018.02.006

Peltonen L, Haanpää S, Lehtonen S (2006) EXTREFLOOD - Tulvariskien hallinta yhdyskuntasuunnittelussa [Management of flood risks in community planning, in Finnish] Finnish Environment Institute, Helsinki. Suomen Ympäristö/The Finnish Environment 22 (2006)

Peltonen-Sainio P, Sorvali J, Müller M, Huitu O, Neuvonen S, Nummelin T, Rummukainen A, Hynynen J, Sievänen R, Helle P, Rask M, Vehanen T, Kumpula J (2017) Sopeutumisen tila 2017: Ilmastokestävyyden tarkastelut maa- ja metsätalousministeriön 
hallinnonalalla [The state of adaptation: analyses of climate resilience in the administrative sector of the Ministry of Agriculture and Forestry, in Finnish] Ministry of Agriculture and Forestry, Helsinki

Penning-Rowsell E, Johnson C, Tunstall S, Tapsell S, Morris J, Chatterton J, Green C (2010) The benefits of flood and coastal risk management: a manual of assessment techniques. The Flood Hazard Research Centre (FHRC). Middlesex University Press, London

Perrels A, Molarius R, Porthin M, Rosqvist T (2008) Testing a flood protection case by means of a group decision support system. Government Institute for Economic Research (VATT), Helsinki. VATT Discussion papers 449.

Perrels A, Veijalainen N, Jylhä K, Aaltonen J, Molarius R, Porthin M, Silander J, Rosqvist T, Tuovinen T (2010) The implications of climate change for extreme weather events and their socioeconomic consequences in Finland. Research reports 158. Government Institute for Economic Research, Helsinki

Pilli-Sihvola K, Haavisto R, Nurmi V, Oljemark K, Tuomenvirta H (2016) Taloudellisesti tehokkaampaa sää- ja ilmastoriskien hallintaa Suomessa [Economically more effective weather and climate risk management in Finland, in Finnish] Prime Minister's Office, Helsinki. Valtioneuvoston selvitys- ja tutkimustoiminnan julkaisusarja 45/2016

Prahl B, Boettle M, Costa L, Kropp JB, Rybski D (2018) Data descriptor: damage and protection cost curves for coastal floods within the 600 largest European cities. Sci Data 5:180034. https://doi. org/10.1038/sdata.2018.34

Priest SJ, Suykens C, Van Rijswick HFMW, Schellenberger T, Goytia SB, Kundzewicz ZW, Van Doorn-Hoekveld WJ, Beyers J-C, Homewood S (2016) The European Union approach to flood risk management and improving societal resilience: lessons from the implementation of the floods directive in six European countries. Ecol Soc 21(4):50. https://doi.org/10.5751/ES-08913-210450

Prutsch A, Grothmann T, McCallum S, Schauser I, Swart R (eds) (2014) Climate change adaptation manual. Lessons learned from European and other industrialised countries. Routledge/ Earthscan, London

Quigley MC, Luke G (2019) Bennetts LG, Durance P, Kuhnert PM, Lindsay MD, Pembleton KG, Roberts ME, White CJ (2019) The provision and utility of science and uncertainty to decisionmakers: earth science case studies. Environ Syst Decis. https:// doi.org/10.1007/s10669-019-09728-0

Raivio T (2006) Viranomaisten varautuminen rankkasadetulvatilanteisiin: Pelastustoiminnan johtokeskustyöskentelyn ja viranomaisten yhteistoiminnan kehittämistarpeet [Official preparedness for flash floods: Development needs for the work in lead centres for rescue operations and for inter-agency collaboration, in Finnish] Gaia Oy, Helsinki

Rajala J (2013) Kokemäenjoen tulvasuojelun historia [The history of flood protection in the River Kokemäenjoki, in Finnish]

Ryan BJ, Franklin RC, Burkle FM, Smith EC (2019) Determining key influences on patient ability to successfully manage noncommunicable disease after natural disaster. Prehosp Disaster Med 34(3):241-250. https://doi.org/10.1017/S1049023X1900431X

Saarela S-R, Söderman T, Lyytimäki J (2015) Knowledge brokerage context factors-what matters in knowledge exchange in impact assessment? Environ Sci Pol 51:325-337

Sairinen R, Järvinen S, Kohl J (2010) Ilmastonmuutoksen ja siihen sopeutumisen sosiaaliset vaikutukset maaseudulla [Rural social impacts of climate change and of adaptation to it, in Finnish]. Reports and studies in social sciences and business studies no 1. University of Eastern Finland, Joensuu. Publications of the University of Eastern Finland
Sane M, Huokuna M (2008) Procedure for identifying automatically potential floods. In: Proc Working Group F, thematic workshop on flood mapping, Dublin, 17-19 September, 2008

Saulnier DD, Brolin Ribacke K, von Schreeb J (2017) No calm after the storm: a systematic review of human health following flood and storm disasters. Prehosp Disaster Med 32(5):568-579. https ://doi.org/10.1017/S1049023X17006574

Schmitt LH, Graham HM, White PC (2016) Economic evaluations of the health impacts of weather-related extreme events: a scoping review. Int J Environ Res Public Health. https://doi.org/10.3390/ ijerph13111105

Silander J, Parjanne A (2012) Tulvariskien euromääräisten vahinkojen ja niiden hallinnan hyötyjen arviointi [Assessment of the economic damages in Euros from floods and of benefits from their management, in Finnish] Finnish Environment Institute, Helsinki. Updated report 26.7.2013

Silander J, Vehviläinen B, Niemi J, Arosilta A, Dubrovin T, Jormola J, Keskisarja V, Keto A, Lepistö A, Mäkinen R, Ollila M, Pajula H, Pitkänen H, Sammalkorpi I, Suomalainen M, Veijalainen N (2006) Climate change adaptation for hydrology and water resources. FINADAPT working paper 6, Finnish Environment Institute Mimeographs. Finnish Environment Institute, Helsinki

SYKE (2019a) Tulvat (Floods, in Finnish) Finnish Environment Institute (SYKE), Helsinki (updated, last visited Sept 2019)

SYKE (2019b) Tulvariskien hallinnan suunnittelu [Planning for flood risk management, in Finnish] Finnish Environment Institute (SYKE), Helsinki 2019 (updated, last visited Sept 2019)

SYKE (2019c) Tulvakarttapalvelu (Flood map service, in Finnish) Frequently updated interactive scalable and linkable multi-layer online map service on floods. Finnish Environment Institute (SYKE), Helsinki (updated, last visited Sept 2019)

SYKE (2019d) Vesistöennusteet: Kokemäenjoen vesistöalue [Watercourse forecasts: Kokemäenjoki River Basin, in Finnish] Daily updated online service for hydrological forecasts for in the Kokemäenjoki River Basin (water level and flow data and forecasts for 42 locations). Finnish Environment Institute (SYKE), Helsinki (update, last visited Sept 2019)

SYKE (2019e) Suomen ympäristökeskus: Tulvatietojärjestelmä TULVATJ [Finnish Environment Institute: Flood information systems TULVATJ, in Finnish] Finnish Environment Institute, Helsinki (updated, last visited Sept 2019)

SYKE (2019f) Pirkanmaan keskeiset säännöstellyt järvet [The central regulated lakes in the Pirkanmaa region, in Finnish]. Finnish Environment Institute, Helsinki (updated, last visited Sept 2019)

Söderholm K, Pihlajamäki M, Dubrovin T, Veijalainen N, Vehviläinen B, Marttunen M (2018) Collaborative planning in adaptive flood risk management under climate change. Water Resour Manage 32:1383-1397. https://doi.org/10.1007/s11269-017-1875-3

Tanoue M, Hirabayashi Y, Ikeuchi H (2016) Global-scale river flood vulnerability in the last 50 years. Sci Rep 6:36021. https://doi. org/10.1038/srep36021

Tuomenvirta H, Haavisto R, Hildén M, Lanki T, Luhtala S, Meriläinen P, Mäkinen K, Parjanne A, Peltonen-Sainio P, Pilli-Sihvola K, Pöyry J, Sorvali J, Veijalainen N (2018) Sää- ja ilmastoriskit Suomessa - Kansallinen arvio [Weather and climate risks in Finland - a national assessment, in Finnish]. Valtioneuvoston kanslia/Prime Minister's office, Helsinki. Valtioneuvoston selvitys- ja tutkimustoiminnan julkaisusarja 43/2018

Unterberger C (2018) How flood damages to public infrastructure affect municipal budget indicators. EconDisCliCha 2:5-20. https://doi. org/10.1007/s41885-017-0015-0

VARELY (2015) Kokemäenjoen vesistöalueen tulvariskien hallintasuunnitelma vuosille 2016-2021 [Flood risk management plan for the Kokemäenjoki River Basin 2016-2021, in Finnish]. VARsinais-Suomen Elinkeino-, Liikenne- ja Ympäristökeskus/ 
South-West Finland Regional Centre for Economic Development, Transport and the Environment, Turku. Raportteja 104/2015

Veijalainen N, Jakkila J, Olsson T, Backman L, Vehviläinen B, Kaurola J (2017) Impacts of climate change on extreme floods in Finland-studies using bias corrected regional climate model data. Hydrol Earth Syst Sci Discuss. https://doi.org/10.5194/ hess-2017-602

Veijalainen N, Lotsari E, Alho P, Vehviläinen B, Käyhkö J (2010) National scale assessment of climate change impacts on flooding in Finland. J Hydrol 391(3-4):333-350. https://doi.org/10.1016/j. hydrol.2010.07.035

Verta OM, Triipponen JP (2011) The Kokemäenjoki river basin flood risk management plan-a national pilot from finland in accordance with the EU floods directive. Irrig Drain 60(Suppl. 1):8490. https://doi.org/10.1002/ird.668

Viglione A, Di Baldassarre G, Brandimarte L, Kuil L, Carr G, Salinas JL, Scolobig A, Blöschl G (2014) Insights from socio-hydrology modelling on dealing with flood risks-roles of collective memory, risk-taking attitude and trust. J Hydrol 518:71-82

Virta H, Rosqvist T, Simola A, Perrels A, Molarius R, Luomaranta A, Honkatukia J (2011) Ilmastonmuutoksen ääri-ilmiöihin liittyvän riskienhallinnan kustannus-hyötyanalyysi osana julkista päätöksentekoa. IRTORISKI-hankkeen loppuraportti [Cost-benefit analysis in risk management related to extreme conditions in climate change as part of public decision-making. Final report of the IRTORISKI project, in Finnish] Finnish Meteorological
Institute, Helsinki. Ilmatieteen laitos - Finnish Meteorological Institute Raportteja - Reports N:o 2011:3

Wahlgren I, Kuismanen K, Makkonen L (2008) Ilmastonmuutoksen huomioiminen kaavoituksessa - tapauskohtaisia tarkasteluja [Accounting for climate change in spatial planning-case considerations, in Finnish] Tutkimusraportti Nro VTTR0398608. 9.5.2008. VTT, Espoo.

Wesselink A, Warner J (2010) Reframing floods: proposals and politics. Nat Culture 5(1):1-14

WGFR (2009) Tulvariskityöryhmän raportti [Report of the working group on flood risks, in Finnish] Ministry of Agriculture and Forestry. MMM, Työryhmämuistio/MoAF Working Group Memo, Helsinki

WHO (2006) Constitution of World Health Organization—-basic documents. Forty-fifth edn, October 2006 suppl, First published 1948. World Health Organization, Geneva

WHO (2016) Noncommunicable diseases in emergencies. World Health Organization, Geneva

Woodward M, Kapelan Z, Gouldby B (2014) Adaptive flood risk management under climate change uncertainty using real options and optimization. Risk Anal 34(1):2014-2092. https://doi. org/10.1111/risa.12088

Zagonari F, Rossi C (2013) A heterogeneous multi-criteria multiexpert decision support system for scoring combinations of flood mitigation and recovery options. Environ Modell Software 49:152-165 